\title{
Longevity of Arachis pintoi cv. BRS Mandobi seeds stored under different conditions ${ }^{1}$
}

\author{
Francisco Humberto Dübbern de Souza ${ }^{2 *}$, Giselle Mariano Lessa de Assis ${ }^{3}$, \\ Judson Ferreira Valentin ${ }^{3}$, Cláudio Cavariani ${ }^{4}$
}

\begin{abstract}
The goal of this work was to evaluate the storage effects under different temperatures, relative humidities (RH) and packaging types on the seed physiological quality and pod moisture content of Arachis pintoi cv. BRS Mandobi. The fruit of this herbaceous, perennial, leguminous species consists of an indehiscent pod containing a single seed, which is not dehulled for planting purposes. Pod samples presenting an initial 5.8\% moisture content and stored under atmospheres presenting 30, 50, 70, 80 and $90 \% \mathrm{RH}$ at $21 \pm 2{ }^{\circ} \mathrm{C}$ reached, respectively, the following equilibrium moisture content (EMC): $5.1 \pm 0.3 \%, 6.2 \pm 0.2 \%, 7.4 \pm 0.3 \%, 8.5 \pm 0.2 \%$ and $11.6 \pm 0.4 \%$. Pod components (pericarp and seed) differed from one another in terms of EMC when stored under the same RH's; on an average, the pericarp EMC was $4.2 \%$ higher than that of the seed. A drastic physiological quality reduction was observed in seeds contained in pods that presented a $6.9 \%$ moisture content when storage temperature was raised from $21 \pm 2{ }^{\circ} \mathrm{C}$ to $30 \pm 3{ }^{\circ} \mathrm{C}$. The physiological quality of seeds was preserved for a longer time in semi-permeable packages; this contributed either to maintain low EMC's or to delay reaching higher pod EMC's, depending on the RH under which they were stored.
\end{abstract}

Index terms: forage peanut, hygroscopic equilibrium, seed packaging, seed quality.

\section{Longevidade de sementes de Arachis pintoi cv. BRS Mandobi armazenadas sob diferentes condições}

\begin{abstract}
RESUMO - O objetivo desse trabalho foi avaliar efeitos de armazenamento sob diferentes temperaturas, umidades relativas do ar (URs) e tipos de embalagens (permeáveis ou semi-permeáveis) sobre a qualidade fisiológica de sementes e o teor de água de vagens de Arachis pintoi cv. BRS Mandobi. O fruto dessa leguminosa herbácea, perene, é uma vagem indeiscente contendo uma única semente que não é debulhado para fins de plantio. Amostras de vagens apresentando teor de água inicial de 5,8\%, armazenadas a $21 \pm 2{ }^{\circ} \mathrm{C}$ sob $30,50,70,80$ ou $90 \%$ de UR alcançaram, respectivamente, os teores de água de equilíbrio (TAE) de $5,1 \pm 0,3 \%, 6,2 \pm 0,2 \%, 7,4 \pm 0,3 \%, 8,5 \pm 0,2 \%$ e $11,6 \pm 0,4 \%$. Os componentes da vagem (pericarpo e semente) diferiram entre si quanto aos TAEs alcançados sob diferentes URs; em média, o TAE do pericarpo foi 4,2\% superior ao da semente. Verificouse drástica redução da qualidade fisiológica das sementes contidas em vagens apresentando teor de água de $6,9 \%$ quando a temperatura local de armazenamento foi aumentada de $21 \pm 2{ }^{\circ} \mathrm{C}$ para $30 \pm 3{ }^{\circ} \mathrm{C}$. A qualidade fisiológica das sementes foi preservada por maior tempo nas embalagens semi-permeáveis as quais possibilitaram a manutenção de níveis baixos de TAEs das vagens ou o retardamento do alcance de teores mais altos, dependendo da UR sob a qual permaneceram armazenadas.
\end{abstract}

Termos para indexação: amendoim forrageiro, embalagem de sementes, equilíbrio higroscópico, qualidade de sementes.

\section{Introduction}

Forage peanut (Arachis pintoi Krap. \& Greg.) is a perennial, stoloniferous and herbaceous Fabacea native species, used as fodder for several animal species, as a

\footnotetext{
${ }^{1}$ Submitted on 05/05/2017. Accepted for publication on 08/14/2017.

${ }^{2}$ Embrapa Pecuária Sudeste, Caixa Postal 339, 13560-970 - São Carlos, SP, Brasil.

${ }^{3}$ Embrapa Acre, Caixa Postal 321, 69900-970 - Rio Branco, AC, Brasil.
}

permanent plant covering of soil surfaces and as an ornamental plant in tropical and subtropical regions. The geocarpic fruit of this species is an indehiscent pod consisting of a pericarp enveloping a single seed composed of an embryo wrapped by a thin tegument (testa); between the seed and the inner

\footnotetext{
${ }^{4}$ Departamento de Produção Vegetal/Agricultura, Universidade Estadual Paulista Júlio de Mesquita Filho, Caixa Postal 237, 18610-307 - Botucatu, SP, Brasil. *Corresponding author<francisco.dubbern-souza@embrapa.br $>$
} 
wall of the pericarp there is an air layer whose volume varies according to the ripeness degree of the seed and the genotype. Since it is not dehulled for planting purposes, this fruit is agronomically considered as 'seed'. For the cultivar BRS Mandobi, on an average, 5 - 8 pods make up one gram.

Such characteristics, which are common to species from this genus, make the hygroscopic relation between seeds and the environment to which they are exposed complex. This topic was widely studied within Arachis hypogaea (Chen, 2000; Corrêa et al., 2007; among others), but no information was found as for $A$. pintoi, which differs from $A$. hypogaea, for example, in size, shape and number of seeds per pod. Another difference between these species is the fact that while true A. hypogaea seeds are removed from the pericarp for planting purposes, $A$. pintoi seeds are not.

The equilibrium moisture content (EMC) reached by seeds exposed to a certain level of relative humidity (RH) depends on their chemical composition; lipid-rich seeds, for example, such as Arachis spp. ones, absorb less water from the environment than those that are rich in starch (Pixton and Warburton, 1971). It also depends on the temperature and RH of the air, the ripeness degree of the seed, its genotype, its physical and sanitary conditions and the method by which equilibrium was obtained (Chen, 2000; Dorner, 2008).

There is a close relation between seed moisture content and longevity (Marcos-Filho, 2015). The physiological quality reduction of seeds from many plant species, especially those with high lipid and protein contents such as the Arachis genus, is accelerated as their moisture content and the temperature to which they are exposed during storage increase (Usberti and Gomes, 1998). The preservation of this quality depends on the initial quality of seeds, and on the environmental conditions of their storage, which may however be modulated by the packaging in which they are kept (Justice and Bass, 1978).

This work was developed with the goal of evaluating storage effects of different combinations of temperatures, relative air humidity and packaging on the physiological quality and moisture content of Arachis pintoi cv. BRS Mandobi seeds.

\section{Material and Methods}

Four consecutive experiments were conducted at the headquarters of Embrapa Pecuária Sudeste (São Carlos SP) between 2008 and 2009, involving lots harvested in 2007 in Rio Branco - AC, through the semi-mechanized method described by Valentim (2011). Pods were washed in order to remove adhered soil and they were dried in the sun. In the period between the harvest and the beginning of the experiments, samples were kept under uncontrolled environmental conditions; however, during the intervals in between experiments, they were stored in a cold $\left(10{ }^{\circ} \mathrm{C}\right)$ and dry $(20 \% \mathrm{RH})$ chamber. With the help of a laboratory seed blower, empty pods were discarded, so that experiments involved only pods containing seeds.

The moisture content was evaluated by the oven-drying method (wet basis) at $105 \pm 3{ }^{\circ} \mathrm{C}$ for $24 \mathrm{~h}$, using two subsamples. Germination tests were carried out in germination paper rolls, with four replications of 50 fungicide-treated (captan) pods per treatment, under the thermal regime of $20^{\circ} \mathrm{C}$ for $16 \mathrm{~h}$ and $35^{\circ} \mathrm{C}$ for $8 \mathrm{~h}$; normal seedlings were counted on the $5^{\text {th }}$ day after the beginning of tests and on the $10^{\text {th }}$ day, when they were ended. At the time, non-germinated seeds were removed from their respective pods and dipped in a $0.5 \%$ triphenyl tetrazolium chloride solution at $35{ }^{\circ} \mathrm{C}$ for four hours; after this period, they were washed and evaluated as for viability. In seedlings and viable seed evaluations, the same criteria proposed for A. hypogaea by the Rules for Seed Testing (Brasil, 2009) were used.

Experiments also involved RH level control inside closed containers, where pod samples were kept for periods that varied according to the experiment. This was obtained through water and glycerin solutions at concentrations calculated to provide desired RH levels, based on parameters proposed by Forney and Brandl (1992). Pods and solution contact was avoided by placing the samples on supports placed inside the containers.

The following experiments were conducted:

\section{Experiment 1: Characterization of pod hygroscopic equilibrium patterns}

This experiment aimed at identifying parameters to obtain seeds with desired moisture contents for the other experiments. Samples containing $40 \mathrm{~g}$ of pods were placed in glass jars with a $10 \mathrm{~cm}$ diameter mouth and a capacity of $5.1 \mathrm{~L}$, closed with a screw-cap sealed with plastic film, and stored in a room maintained at $21 \pm 2{ }^{\circ} \mathrm{C}$. Each jar contained $0.5 \mathrm{~L}$ of a glycerin solution at the necessary concentrations to obtain approximately $30,50,70,80$ or $90 \% \mathrm{RH}$ inside of them. A sample was removed from each jar on the $1^{\text {st }}, 2^{\text {nd }}, 4^{\text {th }}$, $8^{\text {th }}, 16^{\text {th }}, 23^{\text {rd }}$ and $32^{\text {nd }}$ day after the beginning of the storage and evaluated for moisture content. The adopted experimental design was the split-split plot one, in randomized blocks, where the RH was considered as the main plot, and the packing period was considered as the sub-plot, with four replications per treatment (RH levels). The experimental data were submitted to polynomial regression analysis.

\section{Experiment 2: Hygroscopic equilibrium of pod components}

This experiment aimed at identifying the equilibrium 
moisture contents (EMC's) of component fractions of $A$. pintoi cv. BRS Mandobi pods, submitted to atmospheres presenting different RH's. About $280 \mathrm{~g}$ of pods were manually dehulled, and the resulting fractions (pericarp and seed) were divided into equal-sized portions and placed in unclosed glass flasks. Four flasks from each fraction and with intact pods were placed inside $10 \mathrm{~cm}$ diameter glass jars with a $5.1 \mathrm{~L}$ capacity, closed with a screw-cap sealed with plastic film, and stored in a room maintained at $24 \pm 2{ }^{\circ} \mathrm{C}$. Each glass jar contained $0.5 \mathrm{~L}$ of a glycerin solution with the necessary concentration to generate approximately $30,40,50,60,70,80$ or $90 \% \mathrm{RH}$ inside of them. On the $35^{\text {th }}$ day after the beginning of storage period, the samples were removed from the jars and evaluated as for moisture content. The adopted experimental design was the completely randomized one, with four replications per treatment (RH levels); the experimental data were submitted to polynomial regression analysis.

Contributions from each fraction to the total dry mass of the pods were estimated in six replications of 50 manually hulled pods. The dry weight of these two components was obtained after drying at $105^{\circ} \mathrm{C}$ for $24 \mathrm{~h}$. The resulting means were compared by Tukey's test $(\mathrm{p}<0.05)$.

Experiment 3: Effects of different temperatures and relative air humidity levels on the physiological quality of seeds and on the moisture content of pods

Samples containing $100 \mathrm{~g}$ of pods packed in perforated TNT fabric packaging were placed inside $10 \mathrm{~L}$ plastic drums, closed with a screw-cap sealed with plastic film; half of them were kept in a room where $21 \pm 2{ }^{\circ} \mathrm{C}$ prevailed, and the other half was in an oven with forced air circulation regulated at $30 \pm 3{ }^{\circ} \mathrm{C}$. Each drum contained $1 \mathrm{~L}$ of a glycerin solution, at concentrations calculated to provide atmospheres with approximately 65,80 or $85 \% \mathrm{RH}$. Two drums were used for each RH, from which samples were taken at bi-monthly intervals up to the $360^{\text {th }}$ day; in these occasions they were evaluated as for moisture content, germination potential and viability of the remaining seeds at the end of the germination test. The experimental design was the split-split plot one, in randomized blocks (drum), where the RH was considered as the main plot, and the storage period as the sub-plot, with four replications per treatment. The result means were compared by Tukey's test $(p<0.05)$, and germination data were submitted to polynomial regression analysis.

Experiment 4: Effects of packaging types and relative air humidity levels on the physiological quality of seeds and the moisture content of pods

Samples containing $220 \mathrm{~g}$ of pods were placed in four types of packages: glass jars with screw-caps (capacity: $450 \mathrm{~mL}$ ), multi-layered kraft paper packaging closed by seams, cotton fabric packaging and heat-sealed transparent polypropylene film packaging (density: $0.72 \mathrm{~g} / \mathrm{m}^{2}$ ). These samples were packed in $50 \mathrm{~L}$ capacity drums, closed and sealed with plastic film, and kept at $24 \pm 3{ }^{\circ} \mathrm{C}$ during the experimental period. Each drum contained $2.5 \mathrm{~L}$ of a glycerin solution whose concentration was calculated to provide approximately 60,75 or $85 \%$ RH. Samples were removed from the drums at bimonthly intervals up to the $250^{\text {th }}$ day, and were evaluated as for moisture content and germination potential. The experimental design was the split-split plot one, in randomized blocks; the $\mathrm{RH}$ level was considered as the main plot, and the storage period as the sub-plot, with four replications per treatment. Data were evaluated by polynomial regression analysis, and means were compared by Tukey's test $(\mathrm{p}<0.05)$.

\section{Results and Discussion}

The proportion of viable seeds found at the end of the germination tests (dormant seeds) was less than 5\%, and decreased rapidly after the beginning of storage (data not shown). Therefore, results were discussed based on the sum of percentages from these seeds and normal seedlings observed in the germination tests.

\section{Experiment 1:}

The EMC of hygroscopic materials is reached when the vapor pressure of the water composing it equals that of the atmosphere under which it is maintained. As for seeds, besides the water adsorbed and absorbed from the atmosphere, the EMC also includes water resulting from the respiration process of viable seed tissues. Biotic (insect and microorganism) and abiotic (especially mechanical damage and temperature) environmental factors, capable of accelerating respiration, contribute to increases in this content (Marcos-Filho, 2015).

In this experiment, samples of pods initially containing $5.8 \%$ water achieved EMC's of $5.1 \pm 0.3 \%, 6.2 \pm 0.2 \%$, $7.4 \pm 0.3 \%, 8.5 \pm 0,2 \%$ and $11.6 \pm 0.4 \%$ when maintained, respectively, under atmospheres presenting $30,50,70,80$ or $90 \% \mathrm{RH}$ at $21 \pm 2{ }^{\circ} \mathrm{C}$. The higher the $\mathrm{RH}$, the longer it took to reach the EMC for the samples (Figure 1). These data were necessary to allow the selection of RH levels to be included in the other experiments, whose results are presented and discussed below.

\section{Experiment 2:}

Similarly to A. hypogaea (Chen, 2000; Corrêa et al., 2007), the structures composing $A$. pintoi pods (pericarp 


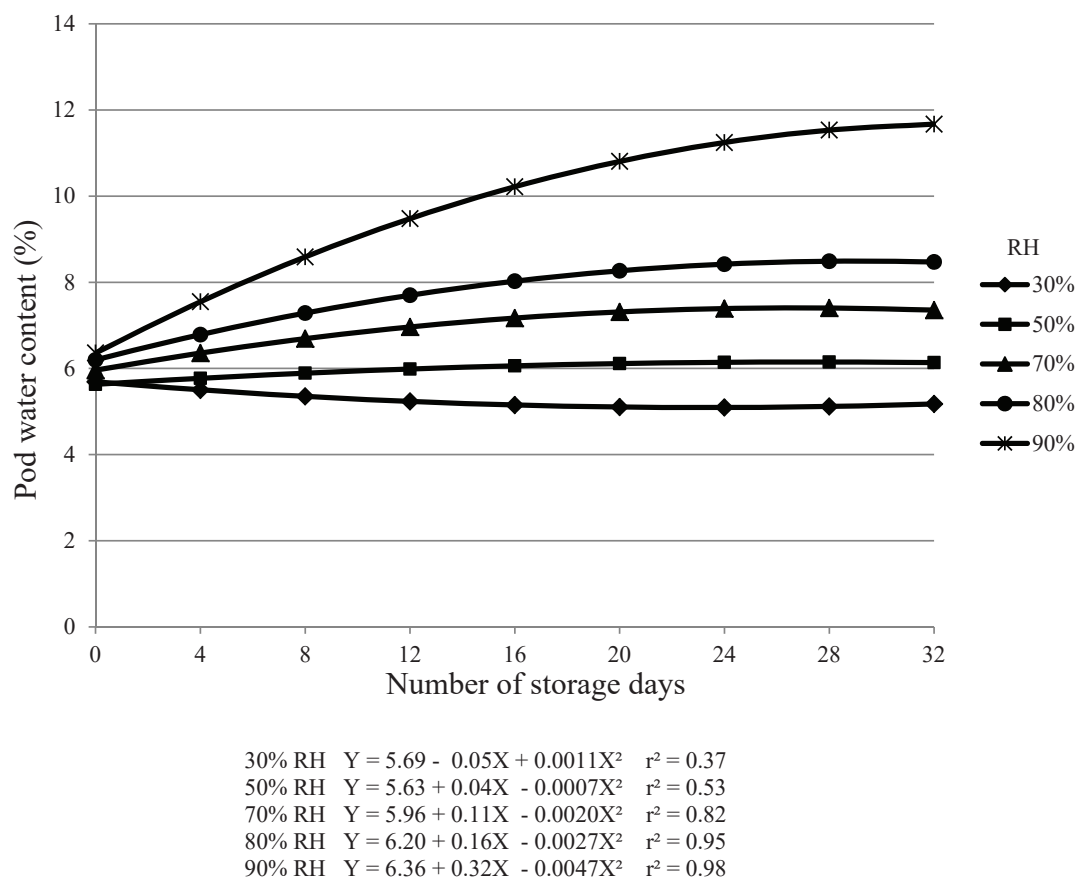

Figure 1. Equilibrium moisture content reached by pod samples of Arachis pintoi cv. BRS Mandobi maintained under different levels of relative air humidity $(\mathrm{RH})$, at $21^{\circ} \pm 2{ }^{\circ} \mathrm{C}$.

and seed) differed from one another in terms of EMC when maintained under identical $\mathrm{RH}$ and temperature conditions (Figure 2). The EMC of the pericarp was higher $(4.7 \%$, on an average) than that of the seed; this may be explained by differences between the hygroscopicity degrees determined by their different morphologies and chemical compositions. The EMC of the pods, although higher than that of the seed $(0.7 \%$, on an average) was close to it, possibly because it represented $71 \%$ of the total dry mass of pods. For the same reasons, based on linear regression coefficients $(\beta)$, it was found that the EMC increase rate of pods ( $\beta=0.104)$, according to increases in the atmospheric $\mathrm{RH}$, was similar to the seed rate $(\beta=0.102)$; the pericarp, however, absorbed water at a higher rate $(\beta=0.128)$.

Thus, three critical EMC are of interest in the case of forage peanut pods: one associated with the pericarp, the other with the seed, and the third one with the intact pod. The authors' experience indicates that the pericarp integrity of $A$. pintoi pods (data not published) is compromised by mechanical impacts during drying, processing, packaging, transportation and planting in a degree that is inversely proportional to its moisture content; such impacts may result in seed exposure to insect and microorganism attacks (Rosseto and Alves, 2008), as well as additional mechanical damages, accelerating its deterioration process. However, increases in moisture content may increase the physiological deterioration degree of seeds as a consequence of the acceleration in its respiratory rate and the development of microorganisms associated with it. That is, whilst increases in the moisture content of pods can potentially contribute to the preservation of the pericarp physical integrity, they could also accelerate the physiological quality loss of the seed. For these reasons, knowing the EMC of intact seeds under varying conditions of $\mathrm{RH}$ and air temperature is essential, due to the implications it has on choosing the packaging type, the conditions of the storage environment and the procedures for drying and processing seeds from this species.

Therefore, it is necessary to determine other absorption/ desorption isotherms of pods, pericarp and seed from this species (and their correlations), as it was done for A. hypogaea (Chen, 2000; Corrêa et al., 2007). It is also necessary to know the physiological behavior of $A$. pintoi seeds stored under different environmental conditions since procedures of seed storage often applied to A. hypogaea (Azeredo et al., 2005) may not constitute appropriate alternatives for $A$. pintoi $\mathrm{cv}$. BRS Mandobi whose indehiscent pods containing a single seed have been used as such for planting purposes.

\section{Experiment 3:}

Except for pods stored at $30 \pm 3{ }^{\circ} \mathrm{C} / 65 \% \mathrm{RH}$, all samples reached higher EMC's than the initial one $(6.6 \%)$ during storage, regardless of the temperature and the $\mathrm{RH}$ of the environment (Table 1). The EMC's of samples kept at $21 \pm 2{ }^{\circ} \mathrm{C}$ 


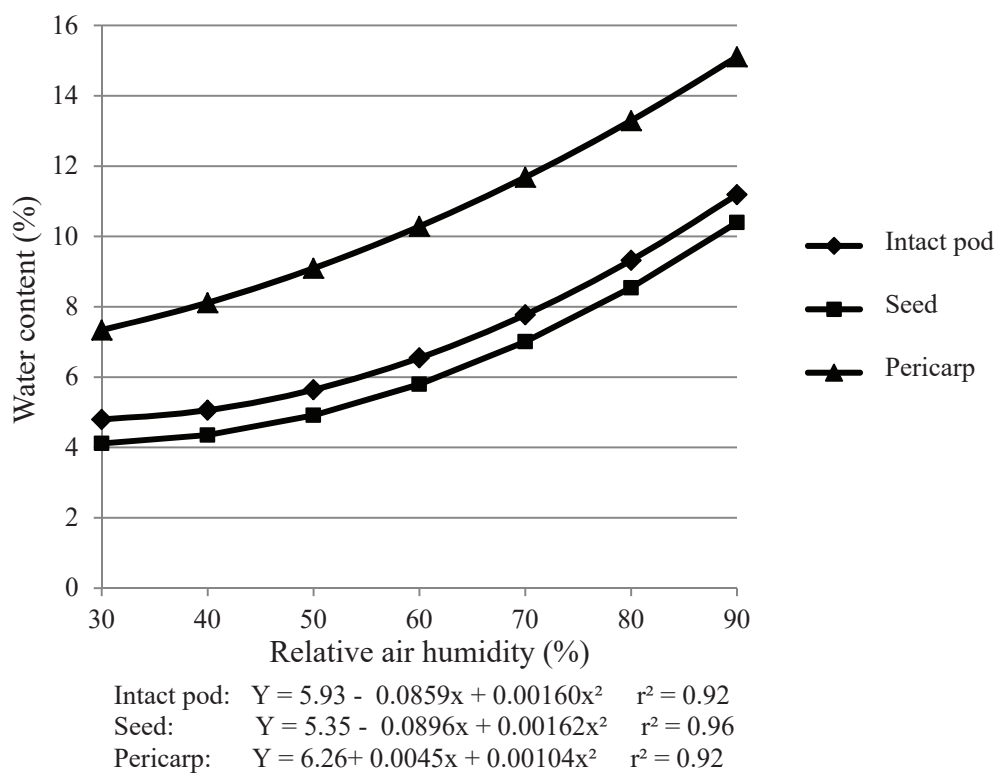

Figure 2. Moisture content of Arachis pintoi cv. BRS Mandobi pods and their components, maintained for 35 days under different levels of relative air humidity (RH) at $24{ }^{\circ} \pm 3^{\circ} \mathrm{C}$.

Table 1. Moisture content (\%) of Arachis pintoi cv. BRS Mandobi pods, stored under different levels of relative air humidity $(\mathrm{RH})$ and temperatures.

\begin{tabular}{|c|c|c|c|c|c|c|c|c|}
\hline \multirow{2}{*}{$\% \mathrm{RH}$} & \multicolumn{8}{|c|}{ Number of storage days } \\
\hline & 0 & 50 & 135 & 200 & 260 & 320 & 380 & Média \\
\hline & \multicolumn{8}{|c|}{ 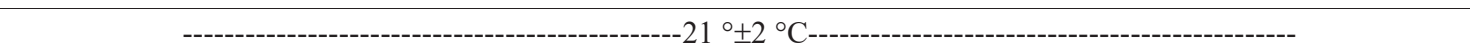 } \\
\hline 65 & $6.6 \mathrm{Ac}$ & $6.4 \mathrm{Cc}$ & $7.1 \mathrm{Ca}$ & 6.9 Cabc & $7.1 \mathrm{Ca}$ & $6.7 \mathrm{Cbc}$ & $6.9 \mathrm{Cabc}$ & $6.8 \mathrm{C}$ \\
\hline 80 & $6.6 \mathrm{Ae}$ & 7.5 Bd & $8.3 \mathrm{Bbc}$ & 8.6 Bab & $8.8 \mathrm{Ba}$ & $8.5 \mathrm{Babc}$ & 8.5 Babc & $8.1 \mathrm{~B}$ \\
\hline 85 & $6.6 \mathrm{Ae}$ & $8.1 \mathrm{Ad}$ & $9.9 \mathrm{Ac}$ & $10.2 \mathrm{Ab}$ & $10.2 \mathrm{Ab}$ & $10.6 \mathrm{Aa}$ & $10.4 \mathrm{Aab}$ & $9.4 \mathrm{~A}$ \\
\hline \multirow[t]{2}{*}{ Mean } & $6.6 \mathrm{~d}$ & $7.4 \mathrm{c}$ & $8.4 \mathrm{~b}$ & $8.6 \mathrm{ab}$ & $8.7 \mathrm{a}$ & $8.6 \mathrm{ab}$ & $8.6 \mathrm{ab}$ & \\
\hline & \multicolumn{8}{|c|}{ - } \\
\hline 65 & 6.6 Aa & $6.6 \mathrm{Ca}$ & $6.4 \mathrm{Ca}$ & $6.5 \mathrm{Ca}$ & $6.4 \mathrm{Ca}$ & $6.4 \mathrm{Ca}$ & $6.6 \mathrm{Ca}$ & $6.5 \mathrm{C}$ \\
\hline 80 & $6.6 \mathrm{Ab}$ & 7.7 Ba & $7.9 \mathrm{Ba}$ & $7.8 \mathrm{Ba}$ & $7.9 \mathrm{Ba}$ & 8.0 Ba & $8.0 \mathrm{Ba}$ & $7.7 \mathrm{~B}$ \\
\hline 85 & 6.6 Ac & $8.8 \mathrm{Ab}$ & $9.5 \mathrm{Aa}$ & 9.4 Aa & $9.4 \mathrm{Aa}$ & $9.5 \mathrm{Aa}$ & $9.6 \mathrm{Aa}$ & $9.0 \mathrm{~A}$ \\
\hline Mean & $6.6 \mathrm{~d}$ & $7.7 \mathrm{c}$ & $7.9 \mathrm{ab}$ & $7.9 \mathrm{bc}$ & $7.9 \mathrm{~b}$ & $8.0 \mathrm{ab}$ & $8.1 \mathrm{a}$ & \\
\hline
\end{tabular}

Values followed by the same letter, upper case in the column or lower case on the line, do not differ by Tukey's test ( $\mathrm{p}<0.05)$.

were higher $(\mathrm{p}<0.05)$ than those reached by the ones kept at $30 \pm 3{ }^{\circ} \mathrm{C}$, at the three tested RH levels. This difference may be explained by the greater ease in releasing into the atmosphere water molecules from the sites where they are adsorbed or absorbed, and the consequent moisture content reduction, promoted by temperature increases (Palipane and Driscoll, 1992).

The 5\% RH increase in the storage atmosphere (from 80 to $85 \%)$ resulted in a significant EMC increase $(\mathrm{p}<0.05)$ of the pods under both tested temperatures (Table 1). These data confirm the results of the first experiment (Figure 1), which showed that the RH elevation in the storage atmosphere, from 80 to $90 \%$, promoted an EMC increase in a higher proportion than those observed for RH increments between lower evaluated levels.

The physiological quality of seeds during storage decreased regardless of temperature and $\mathrm{RH}$ conditions. However, under $21 \pm 2{ }^{\circ} \mathrm{C}$ and $65 \% \mathrm{RH}$, the reduction was less pronounced; under these conditions, the EMC of the pods was approximately $6.9 \%$ (Figure 3 ). The same behavior has been documented with a large number of species whose seeds are orthodox (Roberts, 1973), and it is related to the increase in the respiration rate of viable seed tissues and to the development of microorganisms associated to them, as consequence of EMC increases (Roberts, 1972). In those seeds, low moisture contents contribute to their longevity; 

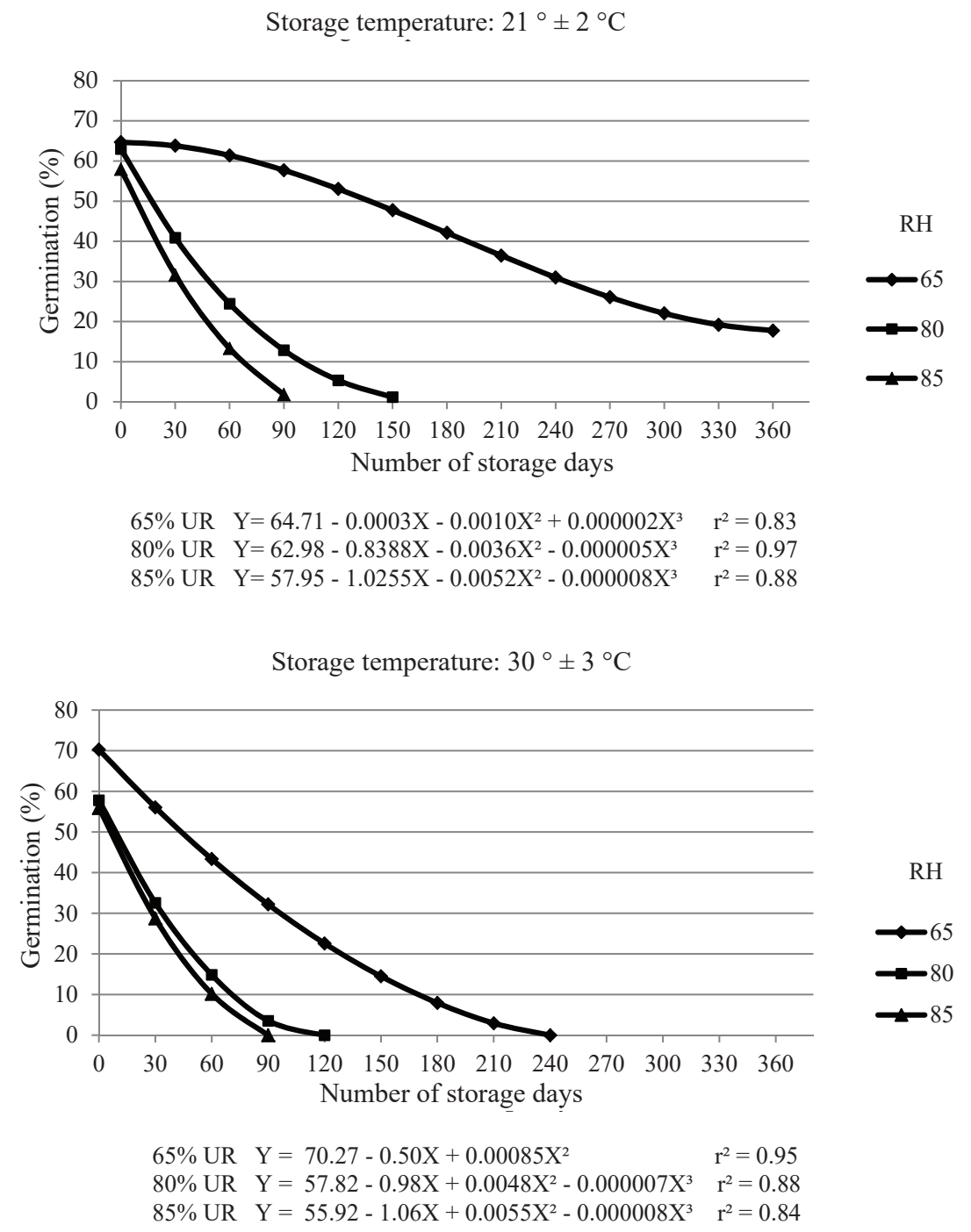

Figure 3. Germination (\%) of Arachis pintoi cv. BRS Mandobi seeds stored under three levels of relative air humidity (RH) and two temperatures.

thus, the preservation of its physiological quality demands atmospheres with RH, temperatures and packages capable of providing and maintaining EMC's within desired limits.

These data reflect the importance of the storage temperature on the physiological quality of $A$. pintoi cv. Mandobi seeds; they presented a drastic quality reduction when the local storage temperature was increased from $21 \pm 2{ }^{\circ} \mathrm{C}$ to $30 \pm 3{ }^{\circ} \mathrm{C}$, regardless of the pod EMC's. These results differ from those reported by Cardozo et al. (1997) who, while comparing seed lots from this same species (cultivar not mentioned), only observed a reduction in the germination potential from the $10^{\text {th }}$ month of storage at $24{ }^{\circ} \mathrm{C}$. In this case, however, seeds with a higher initial viability than those from this experiment, presenting 6.2 to $6.9 \%$ of water, were kept in hermetic packages.

\section{Experiment 4:}

Regardless of the packaging type, changes occurred in the EMC levels of pods stored for 250 days (Table 2), and in the time needed to reach them; the higher the $\mathrm{RH}$, the higher the achieved EMC, and the longer the time required to reach it. The EMC's from samples in cotton fabric and paper packaging (under the three RH's), in plastic packaging under 60 and $75 \%$, and in glass jars under $75 \%$ were analogous. However, EMC's observed in the plastic packaging and glass jars under $85 \%$ RH stood out; in these cases, their reducedpermeability properties may have helped the accumulation of metabolic water in the pods.

As expected, the decrease in the physiological quality of seeds was lower in samples maintained under the lowest RH $(60 \%)$, as shown in Figure 4 . This positive effect on quality was 
Table 2. Moisture content (\%) of Arachis pintoi cv. BRS Mandobi pods stored in four types of packaging and maintained under different levels of relative air humidity (RH).

\begin{tabular}{|c|c|c|c|c|c|c|c|c|}
\hline \multirow{4}{*}{$\begin{array}{l}\text { Storage period } \\
\text { (n. of days) }\end{array}$} & \multicolumn{7}{|c|}{ Moisture content (\%) of pods } & \\
\hline & \multicolumn{4}{|c|}{$\mathrm{RH} \%$} & \multicolumn{4}{|c|}{ RH $\%$} \\
\hline & 60 & 75 & 85 & Mean & 60 & 75 & 85 & Mean \\
\hline & \multicolumn{4}{|c|}{ Plastic packaging } & \multicolumn{4}{|c|}{ Paper packaging } \\
\hline 0 & $6.9 \mathrm{Aa}$ & $6.9 \mathrm{Ab}$ & $6.9 \mathrm{Ac}$ & $6.9 \mathrm{~d}$ & $6.9 \mathrm{Aa}$ & $6.9 \mathrm{Ac}$ & $6.9 \mathrm{Ac}$ & $6.9 \mathrm{c}$ \\
\hline 70 & $6.8 \mathrm{Ca}$ & $7.0 \mathrm{Bb}$ & 7.7 Ab & $7.2 \mathrm{c}$ & $6.3 \mathrm{Cb}$ & $7.1 \mathrm{Bb}$ & 8.6 Ab & $7.3 \mathrm{~b}$ \\
\hline 125 & $6.9 \mathrm{Ca}$ & $7.8 \mathrm{Ba}$ & 8.7 Aa & $7.8 \mathrm{~b}$ & $6.7 \mathrm{Ca}$ & 7.7 $\mathrm{Ba}$ & $9.5 \mathrm{Aa}$ & $7.9 \mathrm{a}$ \\
\hline 190 & $6.9 \mathrm{Ca}$ & $8.0 \mathrm{Ba}$ & 9.1 Aa & $8.0 \mathrm{a}$ & $6.7 \mathrm{Ca}$ & 7.7 $\mathrm{Ba}$ & $9.5 \mathrm{Aa}$ & $8.0 \mathrm{a}$ \\
\hline 240 & $7.1 \mathrm{Ca}$ & $7.9 \mathrm{Ba}$ & $9.0 \mathrm{Aa}$ & $8.0 \mathrm{a}$ & $6.7 \mathrm{Ca}$ & 7.6 $\mathrm{Ba}$ & $9.4 \mathrm{Aa}$ & $7.9 \mathrm{a}$ \\
\hline \multirow[t]{2}{*}{ Mean } & $6.9 \mathrm{C}$ & $7.5 \mathrm{~B}$ & $8.3 \mathrm{~A}$ & & $6.7 \mathrm{C}$ & $7.4 \mathrm{~B}$ & $8.8 \mathrm{~A}$ & \\
\hline & \multicolumn{4}{|c|}{ Cotton fabric packaging } & \multicolumn{4}{|c|}{ Glass jar } \\
\hline 0 & $6.9 \mathrm{Aa}$ & $6.9 \mathrm{Ad}$ & $6.9 \mathrm{Ac}$ & $6.9 \mathrm{c}$ & $6.9 \mathrm{Ab}$ & $6.9 \mathrm{Ad}$ & $6.9 \mathrm{Ad}$ & $6.9 \mathrm{e}$ \\
\hline 70 & $6.3 \mathrm{Cc}$ & $7.3 \mathrm{Bb}$ & $8.8 \mathrm{Ab}$ & $7.4 \mathrm{~b}$ & 7.0 Bab & $7.2 \mathrm{Bc}$ & $7.5 \mathrm{Ac}$ & $7.3 \mathrm{~d}$ \\
\hline 125 & $6.6 \mathrm{Cb}$ & $7.9 \mathrm{Ba}$ & $9.6 \mathrm{Aa}$ & $8.1 \mathrm{a}$ & $7.2 \mathrm{Ca}$ & $7.5 \mathrm{Bb}$ & $8.1 \mathrm{Ab}$ & $7.6 \mathrm{c}$ \\
\hline 190 & $6.8 \mathrm{Cab}$ & $7.9 \mathrm{Ba}$ & $9.6 \mathrm{Aa}$ & $8.1 \mathrm{a}$ & $7.2 \mathrm{Ca}$ & $8.1 \mathrm{Ba}$ & $8.5 \mathrm{Aa}$ & $7.9 \mathrm{~b}$ \\
\hline 240 & 6.7 Cab & $7.7 \mathrm{Ba}$ & $9.5 \mathrm{Aa}$ & $7.9 \mathrm{a}$ & $7.2 \mathrm{Ca}$ & $7.9 \mathrm{Ba}$ & $8.8 \mathrm{Aa}$ & $8.0 \mathrm{a}$ \\
\hline Mean & $6.6 \mathrm{C}$ & $7.5 \mathrm{~B}$ & $8.9 \mathrm{~A}$ & & $7.2 \mathrm{C}$ & $7.7 \mathrm{~B}$ & $8.2 \mathrm{~A}$ & \\
\hline
\end{tabular}

Values followed by the same letter, uppercase on the line or lowercase in the column, do not differ by Tukey's test $(\mathrm{p}<0.05)$.

Plastic packaging

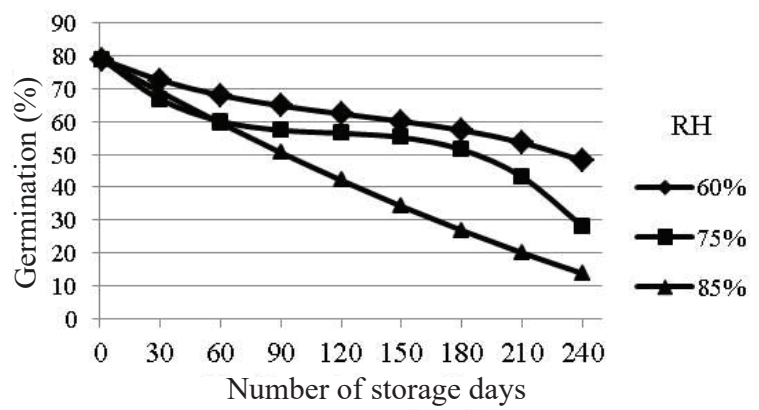
$\begin{array}{lll}60 \% \text { UR } & Y=79.15-0.26 \mathrm{X}+0.0014 \mathrm{X}^{2}-0.000004 \mathrm{X}^{3} & \mathrm{r}^{2}=0.74 \\ 75 \% \text { UR } & \mathrm{Y}=79.41-0.55 \mathrm{X}+0.0045 \mathrm{X}^{2}-0.000013 \mathrm{X}^{3} & \mathrm{r}^{2}=0.90 \\ 85 \% \text { UR } & \mathrm{Y}=79.06-0.34 \mathrm{X}+0.0003 \mathrm{x}^{2} & \mathrm{r}^{2}=0.92\end{array}$

Cotton fabric packaging

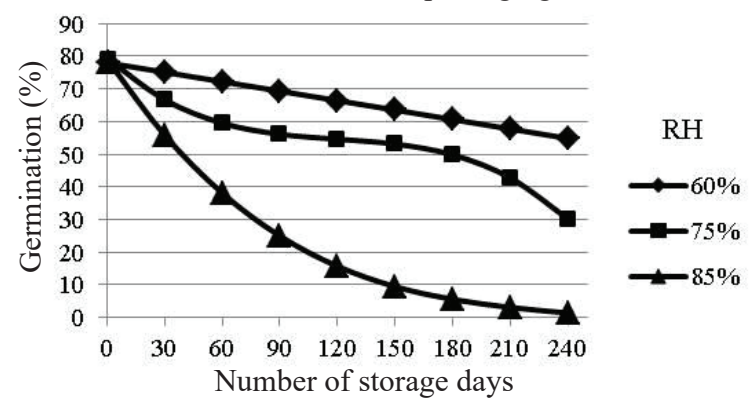

$60 \%$ UR $\quad \mathrm{Y}=76.39-0.10 \mathrm{X}$

$75 \%$ UR $\quad \mathrm{Y}=79.42-0.30 \mathrm{X}+0.0019 \mathrm{X}^{2}-0.000006 \mathrm{X}^{3} \quad \mathrm{r}^{2}=0.91$

$85 \%$ UR $\quad \mathrm{Y}=79.37-0.68 \mathrm{X}+0.0014 \mathrm{X}^{2}$
Glass jar

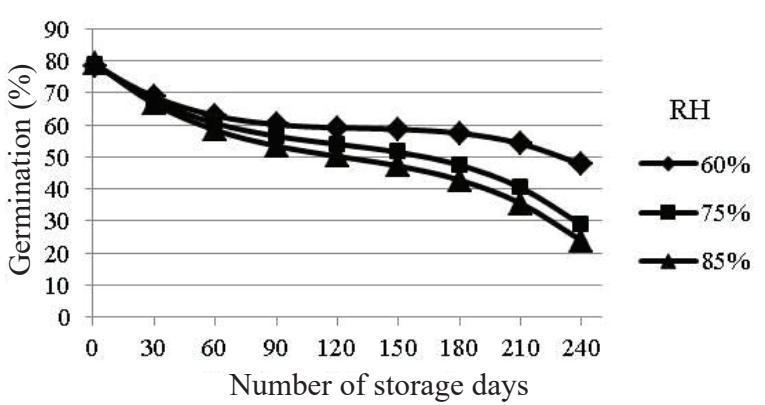

$60 \%$ UR $\quad \mathrm{Y}=78.94-0.42 \mathrm{X}+0.0031 \mathrm{X}^{2}-0.000008 \mathrm{X}^{3} \quad \mathrm{r}^{2}=0.77$ $75 \%$ UR $\quad \mathrm{Y}=79.39-0.48 \mathrm{X}+0.0034 \mathrm{X}^{2}-0.000009 \mathrm{X}^{3} \quad \mathrm{r}^{2}=0.77$ $85 \%$ UR $\quad \mathrm{Y}=79.66-0.53 \mathrm{X}+0.0035 \mathrm{X}^{2}-0.000010 \mathrm{X}^{3} \quad \mathrm{r}^{2}=0.88$

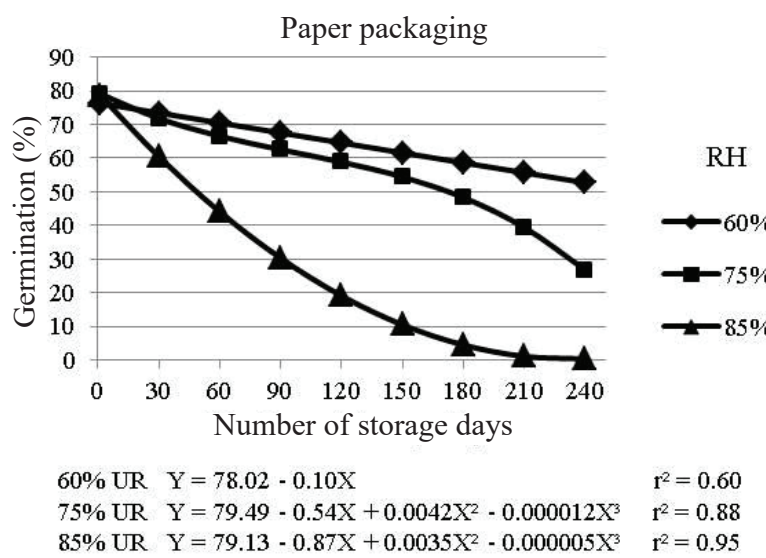

Figure 4. Germination (\%) of Arachis pintoi cv. BRS Mandobi seeds stored in cotton, plastic, paper packaging and capped glass jars under atmospheres with different relative air humidity (RH) at $24{ }^{\circ} \pm 3^{\circ} \mathrm{C}$. 
higher in samples packed in permeable packages than in semipermeable ones. In this case, through regression equations, it was estimated that it would take 378 and 360 days for the germination percentage to reach half the initial percentage (80\%), respectively, in paper and cotton fabric packaging, and 246 and 256 days with plastic packaging and glass jars. Such differences between the types of packaging may have resulted from the fact that in semi-permeable packages the water dissipation from the seeds into the environment was slow, so that they maintained higher moisture contents than those in permeable packages for a longer period.

EMC increases as a consequence of the RH elevation from $60 \%$ to $75 \%$ (Table 2), resulted in decreases in the germination percentages of seeds (Figure 4), but among the packaging types, differences were small; seeds reached half of the initial germination content after approximately 210 (paper packaging), 214 (plastic packaging), 223 (cotton fabric packaging) and 227 (glass jars) storage days.

The RH elevation to $85 \%$ resulted in pods presenting approximately $9.5 \%$ EMC's when kept in permeable packages, whereas in the others they reached $8.5 \%$ (glass) and $8.9 \%$ (plastic) [Table 2]. As a consequence, the number of storage days until reducing by half the initial germination percentage was 57 for paper packaging, 67 for cotton fabric packaging, 128 for plastic packaging and 176 for glass jars (Figure 4). This may have reflected the restriction imposed by semi-permeable packages to the input of humidity, and the consequent delay in reaching higher EMC's than the ones initially presented by the samples. This restriction was greater in glass jars than in plastic packaging.

Thus, the degree of contribution of each packaging type to the preservation of the physiological quality of seeds varied, and it was greater when it contributed to reaching or maintaining low EMC levels of seeds or when it delayed reaching higher contents.

\section{Conclusions}

Samples of Arachis pintoi cv. Mandobi pods, initially presenting 5.8\% moisture content, achieved EMC's of $5.1 \pm 0.3 \%, 6.2 \pm 0.2 \%, 7.4 \pm 0.3 \%, 8.5 \pm 0.2 \%$ and $11.6 \pm 0.4 \%$ when maintained, respectively, under atmospheres presenting $30,50,70,80$ or $90 \% \mathrm{RH}$ at $21 \pm 2{ }^{\circ} \mathrm{C}$. However, the structures composing pods (pericarp and seed) differed as for EMC when maintained under identical RH and temperature conditions; the EMC of the pericarp was higher ( $4.2 \%$, on an average) than that of the seed. There was a drastic reduction in the physiological quality of the seeds contained in pods stored in permeable packaging, presenting $6.6 \%$ moisture content when the storage temperature was increased from $21 \pm 2{ }^{\circ} \mathrm{C}$ to $30 \pm 3^{\circ} \mathrm{C}$. Permeable packaging contributed to preserving the physiological quality of seeds under RH's capable of proportionate pod's EMC's lower than $6.9 \%$. The same effect was provided by semi-permeable packaging which allowed maintaining low EMC's levels in the pods or delayed reaching higher contents, depending on the RH under which they were stored.

\section{Acknowledgments}

The authors thank Dr. Araceli Hackbarth for the assistance in preparing the figures included in this work.

\section{References}

AZEREDO, G.A.; BRUNO, R.L.A.; LOPES, K.P.; SILVA, A.; DINIZ, E.; LIMA, A.A. Conservação de sementes de amendoim (Arachis hypogaea L.) em função do beneficiamento, embalagem e ambiente de armazenamento. Pesquisa Agropecuária Tropical, v.35, n.1, p.37-44, 2005. https://www.revistas.ufg.br/pat/article/ view/2284/2247

BRASIL. Ministério da Agricultura, Pecuária e Abastecimento. Regras para análise de sementes. Ministério da Agricultura, Pecuária e Abastecimento. Secretaria de Defesa Agropecuária. Brasília: MAPA/ACS, 2009. 395p. http://www.agricultura.gov.br/arq_editor/ file/2946_regras_analise_sementes.pdf.

CARDOZO, C.I.; LÓPEZ, Y.; FERGUSON, J.E. Caracterización fisiologica de la semilla de Arachis pintoi Krap. et Greg. nom. nud. en tres ambientes de almacenamiento. Acta Agronómica, v.47, n.2, p. 9-19, 1997. http://revistas.unal.edu.co/index.php/acta_agronomica/ article/viewFile/ 48201/49430

CHEN, C. A rapid method to determine the sorption isotherms of peanuts. Journal of Agricultural Engineering Research, v.75, p.401-408, 2000. http://www.sciencedirect.com/science/article/pii/ S002186349990522X

CORRÊA, P.C.; GONELI, A.L.D.; JAREN, C.; RIBEIRO, D.M.; RESENDE, O. Sorption isotherms and isosteric heat of peanut pods, kernels and hulls. Food Science Technology International, v. 13, n.3, p.231-238, 2007. http://www.journals.sagepub.com/doi/ abs/10.1177/ 1082013207079601

DORNER, J.W. Relationship between kernel moisture content and water activity in different maturity stages of peanut. Peanut Science, v.35, n.2, p.77-80, 2008. www.peanutscience.com/doi/ full/10.3146/ PS07-101.1

FORNEY, C.H.; BRANDL, D.G. Control of humidity in small controlled-environment chambers using glycerol-water solutions. HortTechnology, v.2, n.1, p.52-54, 1992. www.horttech. ashspublications.org/content/2/1/52.full.pdf

JUSTICE, O.L.; BASS, L.N. Principles and Practices of Seed Storage. Agriculture Handbook n.506. US Government Printing Office, Washington, DC.p.142-168, 1978. https://naldc.nal.usda.gov/ download/CAT87208646/pdf 
MARCOS-FILHO, J. Deterioração de sementes. In: MARCOSFILHO, J. Fisiologia de sementes de plantas cultivadas. Londrina: ABRATES, 2015. p.373-446.

PALIPANE, K.B.; DRISCOLL, R.H. Moisture sorption characteristics of inshell macadamia nuts. Journal of Food Engineering, v.18, p.63-76, 1992. www.sciencedirect.com/science/article/pii/ $026087749390075 \mathrm{U}$

PIXTON, S.W.; WARBURTON, S. Moisture content relative humidity equilibrium, at different temperatures, of some oilseeds of economic importance. Journal of Stored Products Research, v.7, p.261-269, 1971.www.sciencedirect.com/science/article/pii/ 0022474X71900245

ROBERTS, E.H. Storage environment and the control of viability. In: ROBERTS, E.H.(Ed.). Seed viability. Syracuse University Press, UK. Chapter 2, 1972. p.14-58.

ROBERTS, E.H. Predicting the storage life of seeds. Seed Science and Technology, v.1, n.3, p.499-514, 1973.
ROSSETO, C.A.V.; ALVES, E.P. Tratamentos pré-germinativos em sementes de Arachis pintoi. Ciência e Agrotecnologia, v.32, n.1, p.174-179, 2008. www.scielo.br/scielo.php?script=sci_ arttext\&pid=S1413-70542008000100025

VALENTIM, J.F. Colheita. In: ASSIS, G. M. L.; VALENTIM, J. F.; ANDRADE, C. M. S. (Eds.). Produção de sementes de Arachis pintoi cv. BRS Mandobi no Acre. Rio Branco, AC: Embrapa Acre, 2011. (Sistema de produção, 4). ISSN 1679-1134. http:// sistemasdeproducao.cnptia.embrapa.br/FontesHTML/Amendoim/ ProducaoSementesArachisAcre/ . Accessed on: January, 5 ${ }^{\text {th }}, 2017$.

USBERTI, R.; GOMES, R.B.R. Seed viability constants for groundnut. Annals of Botany, v.82, p.691-694, 1998. www.jstor. org/stable/42765844 